\title{
LEPTOSPIROSIS IN SLAUGHTERED COWS IN THE TRIANGULO MINEIRO, MINAS GERAIS: PREVALENCE, SEROLOGICAL PROFILE AND RENAL LESIONS
}

\author{
LEPTOSPIROSE EM VACAS ABATIDAS NO TRIÂNGULO MINEIRO: \\ PREVALENNCIA, PERFIL SOROLÓGICO E LESÕES RENAIS
}

\author{
Geórgia Modé MAGALHÃES'; Paula Batista de ALVARENGA²; \\ Alessandra Aparecida MEDEIROS-RONCHI ${ }^{3}$; Thais de Almeida MOREIRA ${ }^{2}$; \\ Ligia Fernandes GUNDIM²; Dayane Olímpia GOMES²; Anna Monteiro Correia LIMA ${ }^{3}$ \\ 1. Professor of South Federal Institute of Minas Gerais, Muzambinho Campus, Muzambinho, MG, Brazil; 2. Postgraduate student, \\ Graduate Program in Veterinary Science, Federal University of Uberlândia - UFU, Uberlândia, MG, Brazil; 3. Associate Professor of \\ Faculty of Veterinary Medicine, Federal University of Uberlândia - UFU, Uberlândia, MG, Brazil. alessandra.medeiros@ufu.br
}

\begin{abstract}
Leptospirosis is a zoonosis that affects several species of domestic and wild animals and is an important cause of economic losses in cattle in Brazil. In this study, we determined the prevalence of bovine leptospirosis in the Triângulo Mineiro region, Minas Gerais, Brazil, identified the most frequent serovars of Leptospira interrogans, and examine the renal pathological changes associated with the disease. Samples of blood serum and kidney fragments from 100 bovine females were collected in cattle abattoir. In the serological investigation $48 \%$ of the cows were positive. The serovars for which there were more reactive animals were Wolffi (24\%), Hardjo (21\%) and Hebdomadis (18\%). Among the positive samples, 14/48 showed antibody titers greater than $1: 100$, and $70.83 \%$ of the seropositive animals responded to more than one Leptospira interrogans serovar. Only one farm did not have seropositive cows and in nine farms studied, six (66.66\%) presented seropositive animals to the Hebdomadis serovar. At the histopathological examination, the most frequent microscopic lesions in positive animals were hyalinization (81.25\%), congestion (81.25\%) and hydropic degeneration (70.83\%). However, these histopathological alterations were also found in kidneys of animals negative to serology, such as hyalinization $(80.77 \%)$, congestion $(48.07 \%)$ and hydropic degeneration (55.77\%) and these findings are unrelated to positivity. Histopathological examination of the kidneys is not indicated to replace the serological diagnosis of leptospirosis, and may be used only as a complementary examination. Despite the low frequency of seropositive animals in the Triângulo Mineiro region, the disease is present in a large number of farms. Noteworthy is the high frequency of serovar Hebdomadis and it can be considered an emerging serovar in the region. The evaluation of the frequency of this serovar in other regions becomes important, and once verified should result in the recommendation of the inclusion of this serovar in the leptospirosis control.
\end{abstract}

KEYWORDS: Leptospira. Microscopic agglutination test. Bovine. Histopathology. Kidney. Hebdomadis serovar.

\section{INTRODUCTION}

Leptospirosis is a high prevalence cosmopolitan anthropozoonosis, considered endemic in cattle causing economic losses due to miscarriages, placental retention, premature births, death, infertility, and decreased milk production by mastitis (JULIANO et al., 2000; TONIN et al., 2010). The disease is caused by a group of bacteria of the order Spirochetales that are distributed in two families: Spirochaetaceae and Leptospiraceae (FAINE, 1999). This last family presents two genera of which only one is pathogenic: Leptospira interrogans. The main serovar causing diseases in cattle is Hardjo (ELLIS, 2015).
Each serovar has a unique natural host being this an important characteristic of the disease (TOMICH et al., 2007). The Leptospira interrogans serovar Hardjo has as its natural hosts bovine animals, in which it can cause chronic reproductive diseases with low pathogenicity in these animals but in high prevalence (GENOVEZ, 2016).

The bacterium is lodged in the kidney after the acute phase causing asymptomatic interstitial nephritis, being eliminated in the urine to the environment for a period of up to 180 days (GENOVEZ, 2016). The lesions in cattle are very similar to those triggered in dogs in many aspects and may occur both acutely septicemic and in the form of chronic nephritis being rarely fatal (JONES; 


\section{HUNT; KING, 2000).}

The definitive diagnosis recommended by the OIE (World Organization for Animal Health) for leptospirosis is MAT (Microscopic Agglutination Test). Such test is serovar-specific and can be difficult to interpret because of cross-reactions between the different serovars, especially in the acute phase of the disease (FAINE, 1999). MAT specificity reduces as the infection time increases (WILLIAN; BERNARD, 1995). In addition, the test does not differentiate vaccine titers from infectious titers, which is a drawback of the test. However, it is still considered a gold standard for the diagnosis of leptospirosis.

Therefore, the paucity of information on leptospirosis in Triangulo Mineiro region, Minas Gerais (MG), Brazil inspired us to determine the prevalence of bovine leptospirosis in this region, identify the most frequent serovars of Leptospira interrogans, examine the renal pathological changes associated with the disease, and correlate these lesions with specific serovars.

\section{MATERIAL AND METHODS}

The study population comprised cattle received for slaughter at selected abattoir in Uberlândia (MG) on the pre-selected days of sampling between October 2011 and February 2012. Samples were systematically collected from slaughter line at abattoir. Blood samples from 100 adult bovine females were collected in $15 \times 75 \mathrm{~mm}$ glass tubes, without anticoagulant and duly identified. The collected material was transported under refrigeration in isothermal box, centrifuged at 710G (Centrifugal Rotation Force - Gravity) for five minutes to obtain the serum, later stored in Eppendorf microtubes of $1,5 \mathrm{~mL}$ and frozen at $20^{\circ} \mathrm{C}$.

In addition to blood collection, the kidneys of these same cows were collected and grossly and histopathologically examined. When there were no visible lesions, fragmentation was standardized covering the cortical and medullary regions in the middle third of the kidney. When macroscopic lesions were visualized, such as icteric, hemorrhagic kidneys, petechiae, depressed or softened white areas, a fragment of the lesion was collected for histopathological examination, in addition to the standardized fragment in the collection.

These samples of kidneys were identified and then immediately fixed in $10 \%$ formalin, processed for histological slides (TOLOSA; RODRIGUES; FREITAS NETO, 2005), and stained with Hematoxylin and Eosin. Microscopic changes were classified according to intensity in: discrete, moderate and severe and according to the type in: degenerative, inflammatory and vascular changes.

Regarding to the serological diagnosis of leptospirosis, the following serovars of Leptospira interrogans were used: Australis, Bataviae, Bratislava, Canicola, Copenhageni, Grippotyphosa, Hardjo, Hebdomadis, Icterohaemorrhagie, Pomona, Pyrogenes, Tarasovi and Wolffi were tested by MAT (Microscopic Agglutination Test) as described by (BRASIL, 1995) using EMJH (ELLINGHAUSEN, MCCULLOUGH, JOHNSON, HARRIS) liquid culture medium enriched with rabbit serum. Animals were considered positive in the screening sera with titres equal or greater than 1:100.

The intensity and frequency of the changes were evaluated with the Chi-squared test. The statistical analyzes were accomplished using the software Action, version 2.9. Positive and negative animals were compared to the presence or absence of microscopic and macroscopic lesions.

\section{RESULTS}

Cows from nine properties located in the Triangulo Mineiro (MG) region were used as subjects. Forty-eight (48\%) animals were positive. The most frequent serovars were Wolffi $(24 \%)$, Hardjo (21\%) and Hebdomadis (18\%) (Figure 1).

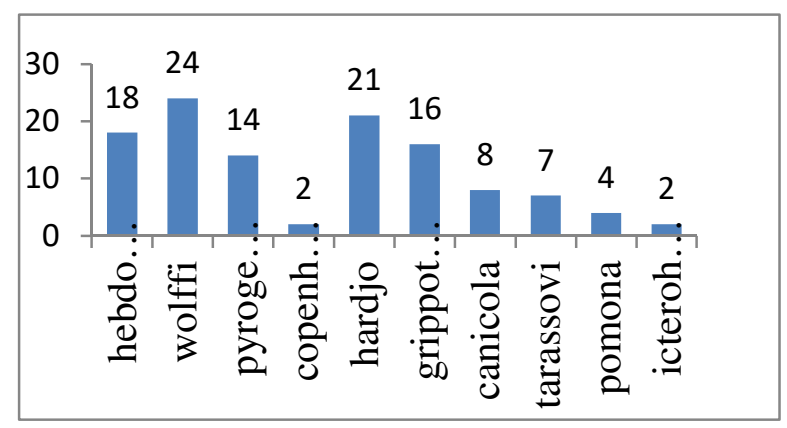

Figure 1. Number of positive cows and frequency of serovars of Leptospira interrogans identified By: MAT (Microscopic Agglutination Test), Uberlândia, Minas Gerais, Brazil. 
Leptospirosis in slaughtered...

Among the positive samples, $14 / 48$ had titer greater than 1:100 (Table 1). About $70.83 \%$ of the seropositive animals reacted to more than one serovar of Leptospira interrogans. One of the
MAGALHÃES, G. M. et al.

properties (I) had $100 \%$ of animals tested positive and the property $\mathrm{F}$ had $100 \%$ negative animals. Nine properties were studied and six (66.66\%) presented seropositive animals to the Hebdomadis serovar.

Table 1. Profile of rural properties with the number of positive animals for leptospirosis, titration and frequency of serovars.

\begin{tabular}{|c|c|c|c|c|c|c|}
\hline $\begin{array}{l}\text { Property/ } \\
\text { Number of } \\
\text { samples }\end{array}$ & Serovar & $\begin{array}{l}\text { Positive } \\
\text { Samples }\end{array}$ & Titre & $\begin{array}{c}\text { Number of } \\
\text { animals } \\
\text { per titre }\end{array}$ & $\begin{array}{c}\text { Number of } \\
\text { seroreagents to } \\
\text { more than one } \\
\text { serovar } \\
\end{array}$ & $\begin{array}{l}\text { Total of } \\
\text { positive } \\
\text { animals }\end{array}$ \\
\hline \multirow{4}{*}{$\begin{array}{c}\text { A } \\
(06)\end{array}$} & Pyrogenes & 02 & $1: 100$ & 02 & \multirow[t]{4}{*}{ (2) } & \multirow{4}{*}{04} \\
\hline & Hebdomadis & 02 & $1: 200$ & 01 & & \\
\hline & & & $1: 100$ & 01 & & \\
\hline & Wolffi & 03 & $1: 100$ & 03 & & \\
\hline \multirow{4}{*}{$\begin{array}{c}\text { B } \\
(15)\end{array}$} & Copenhageni & 01 & $1: 100$ & 01 & \multirow{4}{*}{01} & \multirow{4}{*}{04} \\
\hline & Pyrogenes & 01 & $1: 100$ & 01 & & \\
\hline & Grippotyphosa & 01 & $1: 100$ & 01 & & \\
\hline & Wolffi & 02 & $1: 100$ & 02 & & \\
\hline \multirow{8}{*}{$\begin{array}{c}C \\
(26)\end{array}$} & Pyrogenes & 02 & $1: 100$ & 02 & \multirow{8}{*}{06} & \multirow{8}{*}{09} \\
\hline & Wolffi & 07 & $1: 100$ & 06 & & \\
\hline & & & $1: 200$ & 01 & & \\
\hline & Copenhageni & 01 & $1: 100$ & 01 & & \\
\hline & Grippotyphosa & 02 & $1: 100$ & 02 & & \\
\hline & Hardjo & 05 & $1: 100$ & 05 & & \\
\hline & Hebdomadis & 02 & $1: 100$ & 02 & & \\
\hline & Pomona & 01 & $1: 100$ & 01 & & \\
\hline \multirow{4}{*}{$\begin{array}{c}\mathrm{D} \\
(10)\end{array}$} & Wolffi & 03 & $1: 100$ & 03 & \multirow{4}{*}{03} & \multirow{4}{*}{06} \\
\hline & Hebdomadis & 04 & $1: 100$ & 04 & & \\
\hline & Hardjo & 03 & $1: 100$ & 03 & & \\
\hline & Grippotyphosa & 02 & $1: 100$ & 02 & & \\
\hline \multirow{3}{*}{$\begin{array}{c}E \\
(02)\end{array}$} & Grippotyphosa & 01 & $1: 100$ & 01 & \multirow{3}{*}{01} & \multirow{3}{*}{01} \\
\hline & Hardjo & 01 & $1: 100$ & 01 & & \\
\hline & Hebdomadis & 01 & $1: 100$ & 01 & & \\
\hline $\mathrm{F}(04)$ & 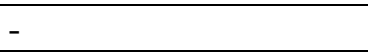 & - & - & - & - & \\
\hline \multirow{9}{*}{$\begin{array}{c}\mathrm{G} \\
(22)\end{array}$} & & & $1: 100$ & 05 & \multirow{9}{*}{09} & \multirow{9}{*}{12} \\
\hline & Grippotyphosa & 07 & $1: 200$ & 01 & & \\
\hline & & & $1: 400$ & 01 & & \\
\hline & Hardjo & 11 & $1: 100$ & 10 & & \\
\hline & & & $1: 400$ & 01 & & \\
\hline & Hebdomadis & 06 & $1: 100$ & 06 & & \\
\hline & Wolffi & 06 & $1: 100$ & 06 & & \\
\hline & Icterohaemorrhagiae & 01 & $1: 100$ & 01 & & \\
\hline & Tarassovi & 04 & $1: 100$ & 04 & & \\
\hline \multirow{9}{*}{$\begin{array}{c}\mathrm{H} \\
(06)\end{array}$} & Grippotyphosa & 02 & $1: 100$ & 02 & \multirow{5}{*}{02} & \multirow{5}{*}{03} \\
\hline & Hardjo & 02 & $1: 100$ & 01 & & \\
\hline & & & $1: 200$ & 01 & & \\
\hline & Wolffi & 01 & $1: 100$ & 01 & & \\
\hline & Hebdomadis & 03 & $1: 100$ & 03 & & \\
\hline & Pyrogenes & 09 & $1: 100$ & 09 & & \\
\hline & \multirow[t]{2}{*}{ Wolffi } & 02 & $1: 100$ & 02 & & \\
\hline & & & $1: 100$ & 02 & & \\
\hline & Canicola & 08 & $1: 200$ & 04 & & \\
\hline
\end{tabular}




\begin{tabular}{|c|c|c|c|c|c|c|}
\hline I & & & $1: 400$ & 01 & & \\
\hline (09) & & & $1: 800$ & 01 & 09 & 09 \\
\hline & Pomona & 03 & $1: 100$ & 03 & & \\
\hline & Tarassovi & 03 & $1: 100$ & 03 & & \\
\hline & Grippotyphosa & 01 & $1: 100$ & 01 & & \\
\hline & Icterohaemorrhagiae & 01 & $1: 100$ & 01 & & \\
\hline
\end{tabular}

(-) Seronegative animals for leptospirosis on MAT serological examination.

The macroscopic lesions most frequently observed in the kidneys of the positive animals were: increase in volume, presence of renal calculi, hyperemia, hemorrhage and pallor of the organ.

The most frequent histopathological

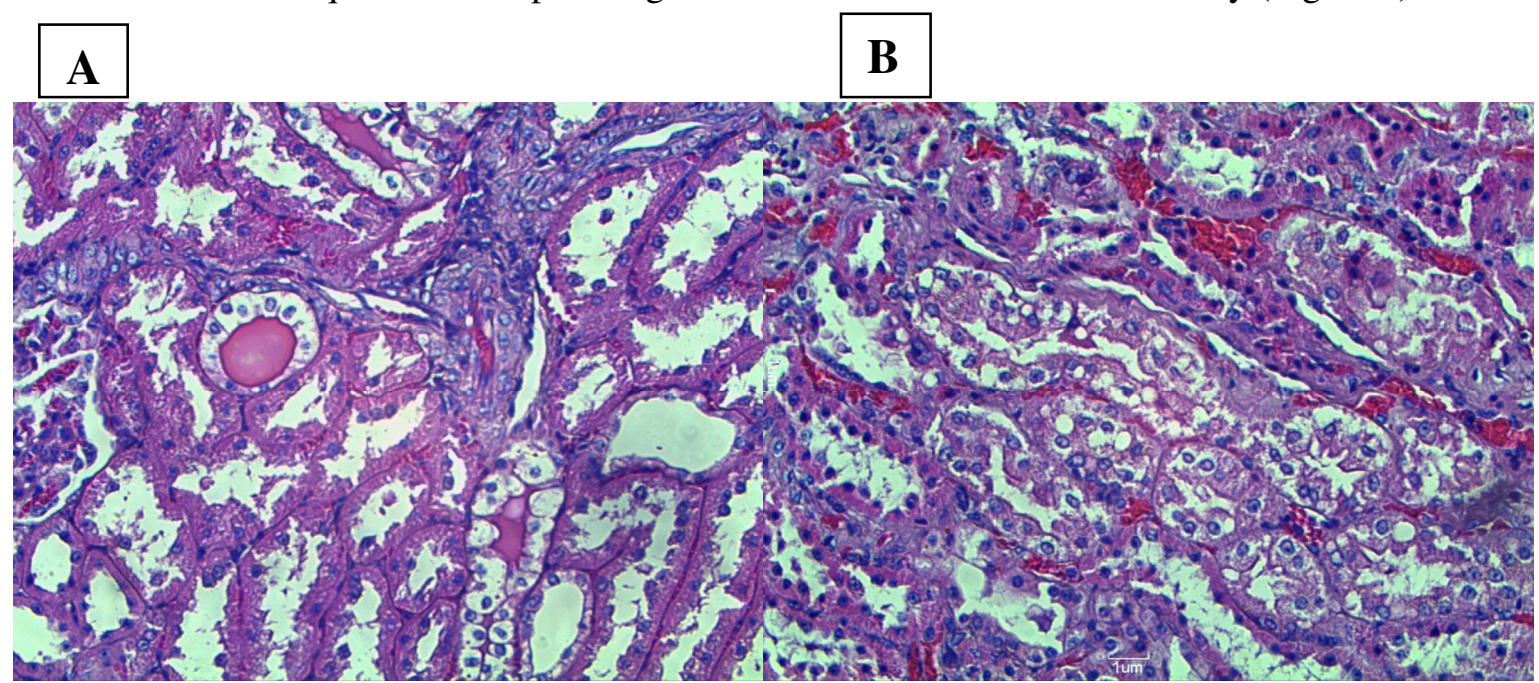

Figure 2. Photomicrographs of bovine kidney.

(A) Hyalinization (arrow); (B) Congestion (black arrow) and hydropic degeneration (red arrow) in the cells of proximal contorted tubules.

Microscopically, among 48 positive animals the most frequent lesions were hyalinization $(81.25 \%)$, congestion (81.25\%), hydropic degeneration $(70.83 \%)$ and interstitial nephritis $(62.50 \%)$. On the other hand, among the negative changes were: hyalinization in the renal tubules (81\%), congestion (81\%), tubular hydropic degeneration (63\%). In most cases (97\%) histological examination showed more than one type of lesion in the same kidney (Figure 2).

\section{B}

serum animals, the frequency of microscopic lesions was similar being the most common lesion hyalinization (80.77\%), congestion $(80.77 \%)$, hydropic degeneration $(55.77 \%)$ and interstitial nephritis (55.77\%) (Table 2).

Table 2. Frequency of histopathological changes in cows positive and negative for leptospirosis.

\begin{tabular}{lcc}
\hline \multicolumn{1}{c}{ Histopathological change } & Positive animals & Negative animals \\
\hline Hyalinization & $39(81,24 \%)$ & $42(80,77 \%)$ \\
Nephritis & $30(62,5 \%)$ & $29(55,77 \%)$ \\
Pyelonephritis & $08(16,67 \%)$ & $11(21,15 \%)$ \\
Congestion & $39(81,24 \%)$ & $42(80,77 \%)$ \\
Glomerulonephritis & $21(43,75 \%)$ & $18(34,61 \%)$ \\
Calcification & $18(37,50 \%)$ & $13(25 \%)$ \\
Hydropic degeneration & $34(70,83 \%)$ & $29(55,77 \%)$ \\
Cellular necrosis & $01(2,08 \%)$ & $01(1,92 \%)$ \\
Steatosis & $05(10,42 \%)$ & $04(7,69 \%)$ \\
Hemosiderosis & $01(2,08 \%)$ & - \\
Amyloidosis & - & $01(1,92 \%)$ \\
Glomerular edema & $03(6,25 \%)$ & $04(7,69 \%)$ \\
\hline
\end{tabular}


There were no differences in the frequency of microscopic lesions between positive and negative animals.

Regarding the distribution of the lesions according to the serovar, in the case of serovar Wolffi all positive animals for this serovar had nephritis (100\%), $83.33 \%$ hyalinization and $62.50 \%$ hydropic degeneration. When the bovine was positive for serovar Hardjo the most frequent lesions were hyalinization (80.95 \%), hydropic degeneration (71.43\%) and congestion (71.43\%), and in the case of bovine positive for Hebdomadis congestion (88.89\%), hydropic degeneration (72.22\%) and nephritis (61.11\%).

\section{DISCUSSION}

In this study $48 \%$ of the cattle were positive for leptospirosis, a frequency similar to that reported by Peiter et al. (2015) of $41.53 \%$. Prevalence of $81 \%$ was reported by Moreira et al. (2010) and Juliano et al. (2000) reported $81.9 \%$ of the positive animals, both in the state of Goiás. In the state of Mato Grosso do Sul, Figueiredo (2007) observed $98.8 \%$ of samples positive for leptospirosis. Thus, the frequency of the disease differs among the various regions studied and this variation is probably related to environmental characteristics.

The most frequent serovars were Wolffi (24\%) and Hardjo (21\%). Peiter et al. (2015) report higher frequency of Hardjo serovars $(8.39 \%)$ and Wolffi (29.46\%) and Juliano et al. (2000) observed higher frequency of Wolffi (36.1\%), Icterohaenorrhagiae (20.5\%) and Hardjo (5.2\%) serovars. Figueiredo (2007) reported $65.6 \%$ of positive animals with Hardjo serovar and $12.3 \%$ with serovar Wolffi. Tonin et al. (2010) reported that the serovar Hardjo was detected in $31.36 \%$ of the samples, while Wolffi serovar was present in $10.90 \%$.

The present study draws attention to the frequency of the Hebdomadis serovar (18\%) which is high when compared to the study performed by Figueiredo (2007) who observed only $2.3 \%$ of seropositive animals to this serovar. The works conducted by Tonin et al. (2010) and Peiter et al. (2015) did not test for serovar Hebdomadis, evidencing the low frequency of this serovar in cattle in Brazil.

In this study, $88.88 \%$ of the rural properties presented at least one seropositive animal, whereas in the state of Paraíba Oliveira et al. (2013) observed only $18.4 \%$ of the rural properties with seropositive animals. This data indicates that the control of the disease through vaccination or even symptomatic treatment in the region studied is precarious.

The majority of the animals had low titers (100 and 200), only 3 animals (6.25\%) had a titer of 400 and one animal (2.08\%) presented a titer of 800 . Cattle usually develop low titers of antibodies to vaccination (100 to 400) and these titers do not indicate that the animal will develop the disease and may be a serological response to the vaccine (MARQUES, 2008). In the case of the animals in this study, since the sample collection was random at the slaughterhouse, these titers probably do not refer to vaccine effects given the short postvaccination period in which the bovine animal has high titers.

Cattle can present acute septicemic form or chronic nephritic type, and in this case the surviving animals present grayish focal lesions in the renal parenchyma, sometimes invading the cortex (JONES; HUNT; KING, 2000). Therefore, the lesions reported in the present study are nonspecific.

Histopathological examination in kidneys of cattle with leptospirosis shows interstitial nephritis with hydropic degeneration of the tubule epithelial cells, as well as cylindrical and granular hyaline (GIRIO; LEMOS, 2007). Nephritis and hydropic degeneration were found in the positive animals of the present study, however, the negative animals also presented similar alterations.

The presence of inflammatory infiltrate in the kidney may be indicative of leptospirosis, but other causes should not be excluded (YERNES and KELIS, 2001). The high rate of inflammatory lesions in animals as positive interstitial nephritis and pyelonephritis (38\%), may be indicative of leptospirosis. However, 40 animals negative to MAT presented nonspecific nephritis, indicating that the presence of this lesion is not exclusive of Leptospira infection. In a recently published article, the authors state that leptospirosis in cattle is not related to the urinary tract, but to the reproductive tract (LOUREIRO; LILENBAUM, 2020). In this case, the histopathological diagnosis alone is not enough to replace the serological diagnosis of leptospirosis.

It was not possible to correlate the occurrence of specific lesions with the frequency of serovars. Microscopic changes like hyalinization appear in similar proportions in several serovars as is the case of hardjo (80.95\%) and wolffi (83.33\%). However, it was noted that in serovar wolffi there was a higher incidence of nephritis (100\%).

\section{CONCLUSIONS}

The occurrence of leptospirosis in the 
Triângulo Mineiro region is low when compared to other regions of Brazil, but it is present in a large number of rural properties.

Most of the cattle in this research were reagents for the Wolffi, Hardjo and Hebdomadis serovars. Wolffi and Hardjo have always been described as frequent in Brazilian herds, but Hebdomadis is not. This serovar can be considered an emerging serovar in the region.

The evaluation of the frequency of this serovar in other regions becomes important, and once verified it should result in advice for the inclusion of this serovar in the leptospirosis control.

Histopathological examination of the kidneys is not indicated to replace the serological diagnosis of leptospirosis and may be used only as a complementary examination. The diagnosis can be based on serological tests, immunohistochemical and detection of the bacterium in renal tissue.

RESUMO: A leptospirose é uma zoonose que afeta várias espécies de animais domésticos e silvestres e importante causa de prejuízos à bovinocultura nacional. Objetivou-se determinar a prevalência da leptospirose e identificar os sorovares de Leptospira interrogans mais frequientes na região do Triângulo Mineiro, além de avaliar microscopicamente as lesões renais e correlacionar estas lesões com sorovares específicos. Foram coletadas amostras de soro sanguíneo e fragmentos de rim de 100 fêmeas bovinas em abatedouro e, destas 100 amostras, $48 \%$ foram positivas. Os sorovares para os quais houve mais animais reagentes foram Wolffi (24\%), hardjo (21\%) e Hebdomadis (18\%). Dentre as amostras positivas, 14/48 apresentaram títulos de anticorpos aglutinantes superiores a 1:100 e notou-se que 70,83\% dos animais soropositivos reagiram a mais de um sorovar de Leptospira interrogans. Somente uma propriedade não possuía vacas sororreagentes para leptospirose e das nove propriedades estudadas, seis $(66,66 \%)$ apresentaram animais soropositivos ao sorovar Hebdomadis. Ao exame histopatológico, as alterações microscópicas mais encontradas em animais positivos foram hialinização $(81,25 \%)$, congestão $(81,25 \%)$ e degeneração hidrópica $(70,83 \%)$. Porém, essas alterações histopatológicas também foram encontradas em rins de animais negativos à sorologia, como hialinização $(80,77 \%)$, congestão $(48,07 \%)$ e degeneração hidrópica $(55,77 \%)$ e estes achados não apresentaram correlação com positividade. $\mathrm{O}$ exame histopatológico dos rins não é indicado para substituir o diagnóstico sorológico da leptospirose, podendo ser utilizado somente como um exame complementar. Apesar da frequência de animais sororreagentes ser baixa na região do Triângulo Mineiro, a doença está presente em um grande número de propriedades. Chama a atenção a alta frequência do sorovar Hebdomadis, podendo ser considerado um sorovar emergente na região. A avaliação da frequência deste sorovar em outras regiões se torna importante, pois uma vez verificada, deve resultar na recomendação da inclusão deste sorovar no controle da leptospirose.

PALAVRAS-CHAVE: Leptospira. Soroaglutinação microscópica. Bovinos. Histopatologia. Rim. Sorovar Hebdomadis.

\section{REFERENCES}

BRASIL. Ministério da Saúde. Fundação Nacional de Saúde. Centro Nacional de Epidemiologia. Coordenação de controle de zoonoses e animais peçonhentos. Programa Nacional de Leptospirose. Manual de Leptospirose. 2. ed. Brasília: Fundação Nacional de Saúde. 1995, 98 p.

ELLIS, W. A. Animal Leptospirosis. In: ADLER B. (eds) Leptospira and Leptospirosis. Current Topics in Microbiology and Immunology, vol 387. Berlin, Heidelberg, Springer, 2015. p.99-138. https://doi.org/10.1007/978-3-662-45059-8_6

FAINE, S. Leptospira and leptospirosis. Melbourne, Australia, 1999. 255 p.

FIGUEIREDO, A. O. Leptospirose bovina: prevalência, variáveis de risco e sorovares predominantes em rebanhos de Mato Grosso do Sul, Brasil. 2007. Campo Grande, 77 f. Dissertação (Mestrado em Saúde Animal) - Faculdade de Medicina Veterinária e Zootecnia, Programa de Pós-Graduação em Ciência Animal.

Universidade Federal de Mato Grosso do Sul. 
GENOVEZ, M. E. Leptospirose em animais de produção. In: MEGID, J.; RIBEIRO, M. G.; PAES, A. C. Doenças infecciosas em animais de produção e de companhia. $1^{\circ}$ edição - Rio de Janeiro, Roca, 2016. p. 376386.

GIRIO R. J. S.; LEMOS, R. A. A. Leptospirose. In: RIET-CORREA, F.; SCHILD, A. L.; LEMOS. R. A. A.; BORGES, J. R. J. Doenças de Ruminantes e Eqüídeos. Santa Maria: Palotti, 2007. p. 331-352.

JONES, T. C.; HUNT, R. D.; KING, N. W. Moléstias causadas por bactérias. In: JONES, T. C.; HUNT, R. D.; KING, N. W. Patologia Veterinária. Manole. Barueri-SP. 6 ed., 2000. p. 476-483.

JULIANO, R. S.; CHAVES, N. S. T.; SANTOS, C. A. D.; RAMOS, L. S.; SANTOS, H. Q.; MEIRELES, L. R.; GOTTSCHALK, S.; CORREAA FILHO, R. A. C. Prevalência e aspectos epidemiológicos da leptospirose bovina em rebanho leiteiro na microrregião de Goiânia-GO. Ciência Rural, Santa Maria, v. 30, n.5, p. 857 862, 2000. https://doi.org/10.1590/S0103-84782000000500020

LOUREIRO, A. P.; LILENBAUM, W. Genital bovine leptospirosis: A new look for an old disease. Theriogenology, Amsterdam, v. 141, p. 41-47, 2020. https://doi.org/10.1016/j.theriogenology.2019.09.011

MARQUES, A. E. Prevalência de anticorpos anti-Leptospira spp. e aspectos epidemiológicos da infecção em bovinos do Estado de Goiás. 2008.Goiânia, 72f. Dissertação (Mestrado) - Universidade Federal de GoiásEscola de Veterinária. 2008. Disponível em:

http://bdtd.ufg.br/tedesimplificado/tde_busca/arquivo.php?codArquivo=122. Acesso em: 09 maio 2011.

MOREIRA, R. Q.; CABRAL, D. D.; LIMA, A. M. C.; OLIVEIRA, P. R. Soroprevalência de anticorpos AntiNeospora caninum e Anti-Leptospira interrogans em duas propriedades de vacas leiteiras com relatos de prejuízos reprodutivos no município de Goiandira, Goiás. Ciência Animal Brasileira, Goiânia, v. 11, n. 2, p. 396-401, abr./jun, 2010. https://doi.org/10.5216/cab.v11i2.3669

OLIVEIRA, R. M.; SILVA, M. L. C. R.; MACÊDO, M. M. S.; DOS SANTOS HIGINO, S. S.; PAULIN, L. M.; ALVES, C. J.; DE AZEVEDO, S. S. Soroepidemiologia da leptospirose e brucelose bovina em propriedades rurais de agricultura familiar do agreste paraibano, Nordeste do Brasil. Arquivos do Instituto Biológico, v. 80, n. 3, p. 303-311, 2013. https://doi.org/10.1590/S1808-16572013000300007

PEITER, M.; ROCHA, J. F. X. D.; PIVOTO, F. L.; AIRES, A. R.; DA ROCHA, R. X.; MANTA BRAGANÇA, J. F.; DO RÊGO LEAL, M. L. Prevalência sorológica de Leptospira spp. em bovinos leiteiros na microrregião de Francisco Beltrão. Veterinária e Zootecnia, v. 22, n. 3, p. 392-395, 2015.

TOLOSA, E. M. C; RODRIGUES, C. J; FREITAS NETO, A. G. Manual de técnicas para histologia normal e patológica. Manole. 2005. 341 p.

TOMICH, R. G. P.; BOMFIM, M. R. Q.; KOURY, M. C, PELLEGRIN, A. O.; PELLEGRIN, L. A.; KO, A. I; BARBOSA-STANCIOLI, E. F. Leptospirosis serosurvey in bovines from Brazilian Pantanal using igG Elisa with recombinant protein LipL32 and microscopic agglutination test. Brazilian Journal of Microbiology, v. 38, p. 674-680, 2007. Disponível em: <http://www.scielo.br/scielo.php?script=sci_arttext\&pid=S151783822007000400017.> Acesso em: 15 jul. 2010. https://doi.org/10.1590/S1517-83822007000400017

TONIN, A. A.; AZEVEDO, M. I.; ESCOBAR, T. P.; CASASSOLA, I.; SANTOS, L. G.; COCCO, M.; MARTINS, J. L. R.; SCHAEFER, P. C.; BADKE, M. R. T. Leptospirose bovina: aumento na incidência da Leptospira interrogans sorovar butembo no rebanho do Estado de Santa Catarina, Brasil. Acta Veterinaria Brasilica, v. 4, n. 4, p. 294-297, 2010.

WILLIAN, V.; BERNARD, D. V. M. Leptospirosis. Veterinary Clinics of North America: Equine Practice, v. 9 , n. 2, p. 435-443, 1995. https://doi.org/10.1016/S0749-0739(17)30410-8 